\title{
Effect of pindolol on intraocular pressure in glaucoma: pilot study and a randomised comparison with timolol
}

\author{
S. ANDRÉASSON ${ }^{1}$ AND K. MQLLER JENSEN ${ }^{2}$ \\ From the 'Department of Ophthalmology, Helsingborg Hospital, Helsingborg, Sweden, and the \\ ${ }^{2}$ Biological Department, Dumex Ltd., Copenhagen, Denmark
}

SUMMARY A pilot study on 10 consecutive patients with newly diagnosed glaucoma and a randomised double-blind study on 18 patients with glaucoma were carried out to investigate the effect of pindolol, a beta-adrenergic blocking agent, on the intraocular pressure (IOP) in patients with glaucoma. The studies showed that pindolol may reduce the IOP and that no significant difference between the effect of timolol $0.5 \%$ and of pindolol $0.25 \%$ could be demonstrated. The serum concentration of pindolol was measured in 9 of the patients, but none had measurable serum levels.

Most of the beta-adrenergic blocking agents have been investigated for their ability to reduce intraocular pressure..$^{1-3}$ Pindolol is a potent betaadrenergic blocking agent without a definite membrane-stabilising effect. ${ }^{4}$ In other studies pindolol has proved able to reduce the IOP. ${ }^{5-9}$ It is therefore an interesting agent, deserving further study.

The two studies reported here were carried out at the Eye Clinic, Helsingborg Hospital, from 1979 to 1981. In the first study 10 consecutive patients with open-angle glaucoma were treated with pindolol eye drops for one month. The second study, which was of randomised, double-blind design, comprised 18 patients with open-angle glaucoma. Nine of the patients were treated with pindolol eye drops $0.25 \%$ and 9 with timolol eye drops $0.5 \%$.

\section{Patients and methods}

STUDY 1

This group comprised 10 consecutive patients with newly diagnosed glaucoma who came to the Eye Clinic in Helsingborg from November 1979 to January 1980. The criteria for inclusion were openangle glaucoma affecting the disc and an IOP $\geqslant 22$ mmHg. Patients suffering from cardiac decompensation, atrioventricular block II-III, or bronchial

Correspondence to Dr Sten Andréasson, Eye Clinic, Helsingborg Lasarett, Helsingborg, Sweden. asthma were excluded. Systemic treatment with a beta-blocker was not permitted.

All the patients were started on treatment with pindolol eye drops $0.25 \%$ twice daily. The same ophthalmologist measured the IOP by applanation tonometry 4 times daily (at 7.30 and 11.00 a.m., and at 1.30 and 3.30 p.m.), according to the following schedule: (A) before starting treatment (day 0); (B) on the first day of treatment (day 1);(C) after 2 weeks of treatment (day 14); (D) after 4 weeks of treatment (day 28).

If the IOP was $\geqslant 22 \mathrm{mmHg}$ after the treatment began the dose was raised to pindolol $0.5 \%$ twice daily, and, if it persisted, pilocarpine eye drops $4 \%$ were also given 3 times daily. To determine the pindolol serum level a blood sample was taken after one week of treatment, 20 minutes after instilling the drops. The serum level was measured by gas chromatography. ${ }^{10}$

\section{STUDY 2}

Eighteen patients with open-angle glaucoma entered this randomised double-blind study. Patients with newly diagnosed glaucoma and patients receiving treatment with pilocarpine or adrenaline were included. None of the patients took a systemic betablocker. All the patients were treated for one month with either pindolol eye drops $0.25 \%$ twice daily or timolol eye drops $0.5 \%$ twice daily. Pilocarpine and adrenaline treatment was discontinued 3 days before these patients entered the study. 


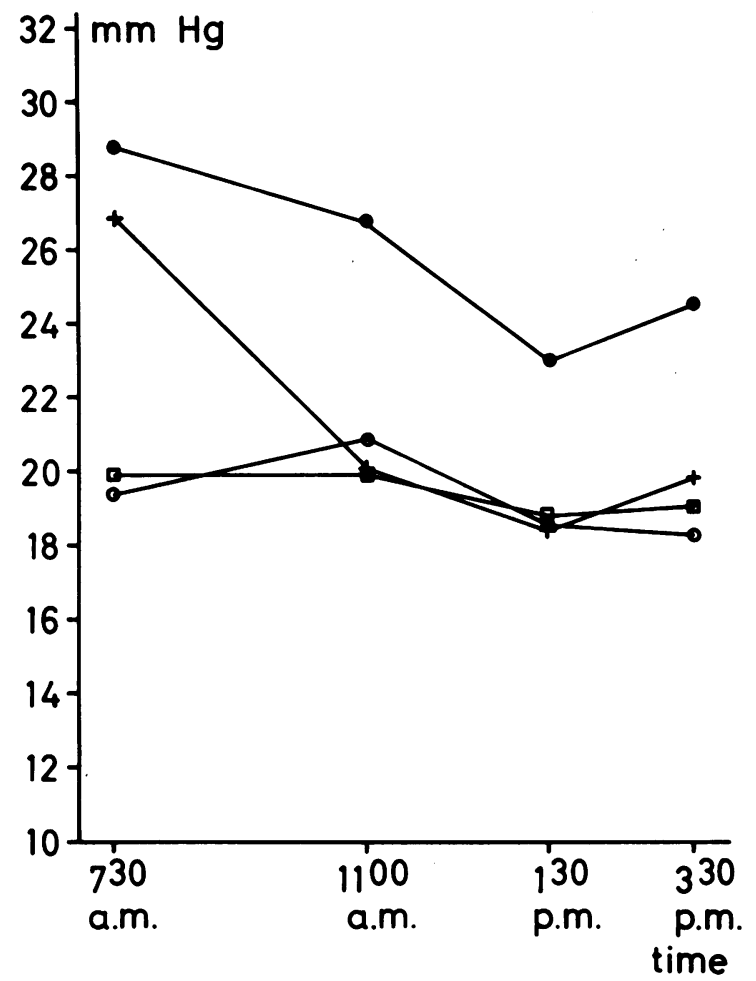

Fig. 1 Mean intraocular pressure before $(-$ day 0$)$ and during treatment $(+-+$ day $1, \square-\square$ day $14,0-\bigcirc$ day 28) of 8 patients with glaucoma with pindolol eye drops.

The same ophthalmologist measured the IOP by applanation tonometry 4 times daily according to the following schedule: (A) before starting treatment (day 0); (B) on the first day of treatment (day 1); (C) after 4 weeks of treatment (day 28). If the IOP did not fall during the treatment, tonus was further measured, and in some cases $4 \%$ pilocarpine eye drops 3 times daily, were given.

The results were statistically evaluated by use of the analysis of variance. All statistical analyses are based on the values from only one of the patient's eyes. Where both eyes had been treated, the mean value was taken unless pilocarpine had been used in one eye, in which case the value from the eye treated solely with pindolol or timolol was used.

The studies were approved by the Ethical Committee, and the patients gave their written consent.

\section{Results}

Fig. 1 shows the results of the pilot study. The mean curves are based on the results from 8 patients. The pilot study showed that pindolol eye drops reduced the pressure in all eyes treated. As with most of the other beta-adrenergic blocking agents, the reduction was marked on the first day of treatment but less as treatment continued.

Pilocarpine eye drops $4 \%$ were given 3 times daily as additional treatment to 3 eyes, 2 later required surgery. Before the start of treatment the IOP in these eyes had been $\geqslant 40 \mathrm{mmHg}$. The serum concentration of pindolol was not measurable and was therefore less than $10 \mathrm{ng} / \mathrm{ml}$.

The randomised double-blind study comprised 18 patients, 4 of whom presented with glaucoma in only one eye. Fig. 2 shows the pressure-reducing effect of pindolol and timolol during 4 weeks of treatment. All

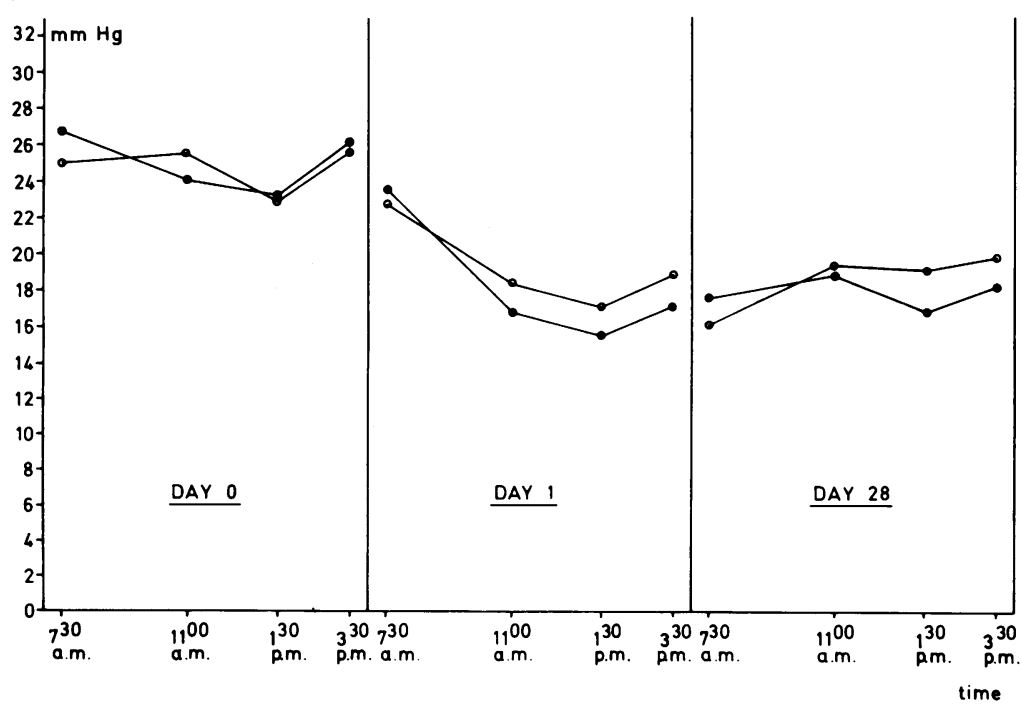

Fig. 2 Mean intraocular pressure before treatment (day 0 ) and on day 1 and day 28 of treatment with pindolol eye drops $0.25 \%(\mathrm{O}-\mathrm{O})$ and timolol eye drops $0.5 \%$ (O-O). 
eyes were treated with either pindolol eye drops $0.25 \%$ or timolol eye drops $0.5 \%$. No significant difference could be demonstrated in the pressurereducing effect of the 2 preparations ( $p \gg 0.05$ ).

Since the number of patients in the study is small the statistical power is somewhat limited. In previous studies timolol has been shown to reduce the intraocular pressure significantly better than placebo. ${ }^{11}$ It may therefore be presumed that at least part of the fall in IOP may be ascribed to an effect of the 2 preparations.

Three patients (one receiving pindolol and 2 receiving timolol) experienced some irritation of the eye. Additional treatment with pilocarpine $4 \%$ was necessary in 3 eyes ( 2 timolol and 1 pindolol). The IOP in these eyes had been $\geqslant 40 \mathrm{mmHg}$ before the start of treatment.

\section{Discussion}

The purpose of the pilot study and the randomised double-blind study was to investigate the effect of the beta-adrenergic blocking agent, pindolol, on IOP in the treatment of glaucoma. Both studies showed that pindolol eye drops reduced the IOP in glaucoma during the course of 4 weeks of treatment.

The double-blind study shows that both pindolol and timolol reduced IOP during 4 weeks of treatment. No significant difference between the effect of pindolol eye drops $0.25 \%$ and timolol eye drops $0.5 \%$ was found. Both preparations were well tolerated by all patients. The pressure-reducing effect of pindolol in long-term treatment and titration of the optimal concentration of pindolol eye drops need further study.

Pindolol eye drops for both studies were supplied by Dumex Ltd., Copenhagen. The authors thank Mrs B. Ullert and Mrs K. Falkman for their assistance and Bjørn Andersen, chief physician, for his help with the statistical analyses.

\section{References}

1 Vale J, Gibbs ACC, Phillips CI. Topical propranolol and ocular tension in the human. Br J Ophthalmol 1972; 56: 770-5.

2 Vale J, Phillips CI. Practolol (Eraldin) eye drops as an ocular hypotensive agent. Br J Ophthalmol 1973; 57: 210-4.

3 Wettrell K. Pandolfi M. Effect of topical atenolol on intraocular pressure. Br J Ophthalmol 1977; 61: 334-8.

4 Zimmerman TJ, Boger WP. The beta-adrenergic blocking agents and the treatment of glaucoma. Surv Ophthalmol 1979; 23: 347-62.

5 Bonomi L, Steindler P. Effect of pindolol on intraocular pressure. Br J Ophthalmol 1975; 59: 301-3.

6 Ildikó S, István T. Helyileg alkalmazott pindolol (Visken, LB46) szemnyomáscsökkentó hatása glaukomânál. Szemészet 1978; 115: 204-8.

7 Smith SE, Smith SA, Reynolds F, Whitmarsh VB. Ocular and cardiovascular effects of local and systemic pindolol. $\mathrm{Br} J$ Ophthalmol 1976; 63: 63-6.

8 Rowley S, Staunton JE, Tosch A, Stewart-Jones JH, Edgar DF, Turner $P$. A noninvasive tonometer in the measurement of the effects of pindolol and timolol on intraocular pressure in normal subjects. Br J Ophthalmol 1981; 65: 536-8.

9 Tyas C, Stewart-Jones JH, Edgar DF, Turner P. The effect of $0.25 \%$ and $0.5 \%$ pindolol on intraocular pressure in normal human volunteers. Curr Med Res Opin 1981; 7: 550-2.

10 Degen PH, Riess W. Simplified method for the determination of oxprenolol and other $\beta$-receptor blocking agents in biological fluids by gas liquid chromatography. J Chromatogr 1976; 121: $72-5$.

11 Zimmerman TJ, Kaufman HE. Timolol. A $\beta$-adrenergic blocking agent for the treatment of glaucoma. Arch Ophthalmol 1977; 95: $601-4$. 